\title{
Structure and properties of solid BK6-OM alloy after electrosintering
}

\author{
N.M.Prokopiv ${ }^{1}$, E.S.Gevorkyan ${ }^{2}$, R.V.Vovk ${ }^{3}$, \\ O.V.Harchenko ${ }^{1}$, V.A.Chishkala ${ }^{3}$ \\ ${ }^{1}$ V.Bakul Institute for Superhard Materials, 2 Avtozavodskaya Str., \\ 04074 Kyiv, Ukraine \\ ${ }^{2}$ Ukrainian State University of Railway Transport, 7 Feierbakh Sq., \\ 61050 Kharkiv, Ukraine \\ ${ }^{3}$ V.Karazin Kharkiv National University, 4 Svobody Sq., \\ 61022 Kharkiv, Ukraine
}

\section{Received December 5, 2017}

In the paper we describe the results of the structure formation and physicomechanical properties of WC-Co hard alloy from the standard especially fine-grained BK6-OM mixture of KZTS (Russia) in electrosintering (ES) process with the use of a constant electric current $(I=3000 \mathrm{~A})$ in a graphite mold in vacuum under pressure of $40 \mathrm{MPa}$ and temperatures above $\left(1320^{\circ} \mathrm{C}\right)$ and below $\left(1220^{\circ} \mathrm{C}\right)$ of the solidus line of phase diagram. For comparison, samples from this mixture are sintered according to the standard technology in vacuum. The advantage of ES in conditions of the solid phase interaction $\left(1200^{\circ} \mathrm{C}\right)$ is shown for obtaining the two-phase structure of hard alloy with high-density, without signs of recrystallization of carbide grains, from the standard mixture of BK6-OM, which increases by $30 \%$ the thermal conductivity, hardness, and fracture toughness compared to the Sun. The mechanism of destruction of the samples after ES in conditions of impact loading is established.

Keywords: hard alloy, electrosintering, tungsten carbide, mechanical properties, vacuum sintering.

Исследованы и обобщены результаты структурообразования и физико-механические свойства твердого сплава группы WC-Co из стандартной, особенно мелкозернистой смеси ВК6-ОМ производства КЗТС (Россия) в процессе электроспекания с использованием постоянного электрического тока $(I=3000$ А) в графитовой пресс-форме в вакууме под давлением $40 \mathrm{MПа} \mathrm{и} \mathrm{температурах} \mathrm{выше}\left(1320^{\circ} \mathrm{C}\right)$ и ниже $\left(1220^{\circ} \mathrm{C}\right)$ линии солидус диаграммы состояния. Для сравнения образцы из этой смеси спекали по стандартной технологии в вакууме. Показано преимущество ЭС в условиях твердофазного взаимодействия $\left(1200^{\circ} \mathrm{C}\right)$ для получения двухфазной высокоплотной, без признаков рекристаллизации карбидных зерен, структуры твердого сплава из стандартной смеси ВК6-ОМ, что позволило на 30 \% повысить, по сравнению с ВС, теплопроводность, твердость и трещиностойкость. Установлен механизм разрушения образцов после ЭС в условиях ударной нагрузки.

Структура та властивості твердого сплаву ВК6-ОМ після електроспікання. М.М.Прокопів, Е.С.Геворкян, Р.В.Вовк, О.В.Харченко, В.О.Чишкала.

Досліджено та узагальнено результати структуроутворення та фізико-механічних властивостей твердого сплаву групи WC-Co з стандартної, особливо дрібнозернистої суміші ВК6-ОМ виробництва КЗТС (Росія) у процесі електроспікання з використанням постійного електричного струму $(I=3000$ А) в графітовій прес-формі у вакуумі під 
тиском 40 МПа і температурах вище $\left(1320^{\circ} \mathrm{C}\right)$ і нижче $\left(1220^{\circ} \mathrm{C}\right)$ лінії солідус діаграми стану. Для порівняння зразки з цієї суміші спікали за стандартною технологією у вакуумі. Показано перевагу EC в умовах твердофазної взаємодії (1200C) для отримання двухфазної високощильної, без ознак рекристалізації карбідних зерен, структури твердого сплаву зі стандартної суміші ВК6-ОМ, що дозволило на 30 \% підвищити, у порівнянні з ВС, теплопровідність, твердість і тріщиностійкість. Встановлено механізм руйнування зразків після ЕС в умовах ударного навантаження.

\section{Introduction}

Analysis of analytical and information sources related to metalworking industry of Ukraine [1,2] indicates that submicron solid alloys of WC-Co group (6-10\% by mass) are characterized by the high level of hardness and mechanical strength. Tools from such alloys are produced by 200 world companies (Sweden, Germany, USA, Japan, South Korea, etc.). A similar tool from especially fine-grained hard alloys under the brand OM [3-5] is made by Russian manufacturers. In Ukraine there is no production of metal cutting tools from submicron hard alloys. Therefore, all requirements of the domestic metalworking industry are met through imports.

As it turned out, the main difficulties in obtaining the high quality submicron hard alloys of the WC-Co group consist in the formation of a high-density, fine-grained homogeneous structure without fragile $\eta$-phase. It is known that traditional sintering technologies (in methane-hydrogen medium [6] and in vacuum [3,4]), which were developed earlier in $30 \mathrm{~s}-40 \mathrm{~s}$ years of the last century, do not provide the formation of a structure with completely eliminated residual micropores. For objective reasons, they are still used in the technology of industrial production by domestic firms. To insignificant extent, their properties are improved by additional thermal-compression treatment (TCT) under gas pressure of $5 \mathrm{MPa}$ [7]. The reason for this can be also the use of submicron powder mixtures of low quality, the characteristics of which are regulated by GOST-74. As our experience shows, in structure of the hard alloys from such powders, which are sintered according to the traditional technologies, the fragile $\eta$-phase is present in most cases, as a consequence, of decrease in plastic properties. Therefore, the preliminary normalizing the sintering at $900-950^{\circ} \mathrm{C}$ in the methane-hydrogen environment is required operation in the technology of their production [6].

For the solving the problem of high structure density, especially submicron hard alloys, advanced world firms implement the vacuum compression sintering technology under gas pressure up to $10 \mathrm{MPa}$, which was developed back in the $80 \mathrm{~s}$ of the last century [8,9]. According to the open sources of information, the general disadvantage of submicron alloy (for example WC-6 wt.\% Co) obtained by implementing the above technologies, regardless of the manufacturer, is its low fracture toughness. This significantly reduces the operational properties when cutting under the conditions of significant static and dynamic mechanical loads.

Today in V.M.Bakul ISM NASU (Kyiv) the intensive searching works are carried out using both traditional and non-traditional technological methods for obtaining the domestic highly competitive hard alloys. This concerns the development of the domestic vacuum compression technology for sintering under the gas pressure up to 2.53.0 $\mathrm{MPa}$ and its technical support for the production of the highly competitive submicron hard alloys and manufacture of the tools from them $[10,11]$. At the same time, special attention is also paid to obtaining the powder mixtures in connection with specific synthesis conditions.

On the basis of analysis of the problem of obtaining the submicron and nanostructured hard alloys, it is recommended in [12] to develop high-energy methods based on high-speed compacting of the initial charge upon heating to the sintering temperature. In [3] it was shown the high efficiency of static and dynamic hot pressing for production of the high-quality hard alloys of the WC-Co group (Co 10, 15, $20 \%$ by wt.) under the condition of long solid-phase annealing. But there is no information on the effectiveness of this method for obtaining the medium cobalt (up to $10 \%$ by wt.) hard alloy, especially fine-grained, for instrumental purpose.

Among the most promising there is the hot-pressing technology with the use of constant pulsating (spark-plasma sintering, SPS) [14], and alternating (electric sintering, ES) [15] electric current $(I=3000 \mathrm{~A})$. In this case, the effect of the current on the sintering process has thermal (source of Joule heat) and athermic (electromigration, electroplasticity, ponderomotive forces) na- 
ture. It is also possible to form a spark discharge in microvolumes between the powder particles, the probability of which is more realistic in the case of using the electrically conductive powders, especially at the initial stage with insufficient contacts. So in $[17,18]$ information is given on the increase in the operational stability of cutting inserts made of hard alloy and ceramics, which were are obtained by the SPS technology.

The authors of domestic ES technology in vacuum with the example of Tungsten carbide [16], $\mathrm{Al}_{2} \mathrm{O}_{3}-50 \% \mathrm{WC}$ (by wt.) have shown its efficiency for providing the high mechanical characteristics. In addition, the technical support of this technology is much simpler and cheaper than the technical support of the SPS method [18, 21], and therefore it has great prospects for introducing the high-competitive domestic products from refractory compounds into the production of highly competitive products based on the "price-quality" criterion. This, in turn, is of decisive importance in the development of the new materials of multifunctional designation with given technological parameters [22-27].

To date, there is no information about the materials science researches of the effect of the ES method on structure and properties, especially the fine-grained carbide WC-Co, using a cheap commercial grade OM powder mixture. The object of this work is to research the structure formation and formation of physical and mechanical properties of the hard alloy in the process of ES in vacuum from the commodity of standard especially fine-grained powder mixture VK6-OM produced by KZTS (Russia).

\section{Experimental}

As a starting batch, the standard mixture of VK6-OM produced (2014) by Kirovgrad hard alloys plant (KZTS, Russia) was used. Electrosparking (ES) of the samples measuring $\varnothing 18 \times 4 \mathrm{~mm}^{2}$ was obtained in a graphite mold $(I=3000$ A) a) in vacuum at 1220 and $1320^{\circ} \mathrm{C}\left( \pm 20^{\circ} \mathrm{C}\right)$ isothermal holding for $3 \mathrm{~min}$ and pressure $40 \mathrm{MPa}$. These temperature values ensure that the process is carried out in accordance with the conditions of solid- and liquid-phase interaction in the WC-Co system. The heating rate was $250 \mathrm{deg} . / \mathrm{min}$. For comparison, the samples were also obtained by sintering in vacuum (VS) at temperature of $1400^{\circ} \mathrm{C}$ and at isothermal sintering time of $20 \mathrm{~min}$. In this case, one batch of the samples was presintered at $950^{\circ} \mathrm{C}$ in methane-hydrogen environment according to [6], which would prevent the formation of $\eta$-phase in the structure of the alloy during the final sintering.

The chemical integral composition was determined by SEM. The residual microporosity in the structure of the samples was evaluated in accordance with GOST 9391-80 by optical microscope MIM-6 with magnification of $\times 100$, the physicomechanical properties were determined by standard methods. The grain size distribution of WC grains, Co layers and their average dimensions were determined by the Kikuchi method (diffraction of electrons by reflection) [19]. In the images of the alloy structure, carbide grains of different crystallographic orientation are painted in different colors, providing a clear fixation of the grain boundaries. The method is very sensitive to the perfection degree of the structure, and therefore it is effective for the study of objects of small $\left(1 \mu^{3}\right)$ size.

The polished samples were subjected to fracture resistance according to Palquist at load of $P=550 \mathrm{~N}$ on the Vickers pyramid. Hardness was determined by Rockwell on the TK-2 device and by Vickers for loading on a diamond pyramid $P=300 \mathrm{~N}$. The density of the samples was measured by hydrostatic weighing. Thermal conductivity was determined by the method described in [20].

\section{Results and discussion}

In the structure of the samples after VS without preliminary normalizing sintering and the samples after ES at $1320^{\circ} \mathrm{C}$, the $\eta$-phase inclusion of the "lake" type was detected, the presence of which was unacceptable from the point of view of the requirements for the structure of a qualitative hard alloy. For this reason, these samples were not further investigated. This may be a consequence of the insufficient degassing of the sample, as in $\mathrm{BC}$, due to the high rate of heating and compaction. The results of chemical analysis of the samples from the

Table 1. Chemical composition of samples from mixture of VK6-OM after VS and ES

\begin{tabular}{|c|c|c|c|c||}
\hline \multirow{2}{*}{$\begin{array}{c}\text { Samples } \\
\text { sintering } \\
\text { conditions }\end{array}$} & \multicolumn{4}{|c|}{ Content of elements in \% by weight } \\
\cline { 2 - 5 } & C K & O K & Co K & W L \\
\hline VS & 5.67 & 0.18 & 5.89 & 88.24 \\
ES & 6.19 & 0.22 & 5.82 & 88.17 \\
\hline
\end{tabular}


Table 2. Dimensional characteristics of grains and pores of samples after vacuum (VS) and electrosparking (ES), in comparison with analogues of world firms

\begin{tabular}{|c|c|c|c|c|c|}
\hline \multirow{2}{*}{$\begin{array}{l}\text { Samples } \\
\text { sintering } \\
\text { conditions }\end{array}$} & \multicolumn{5}{|c|}{ Structure characteristics } \\
\hline & $\begin{array}{l}\text { Bulk fraction of } \\
\text { small pores, } \%\end{array}$ & $\begin{array}{l}\text { Size of large } \\
\text { pores, } \mu \mathrm{m}\end{array}$ & $\begin{array}{l}\text { Powder size Co } \\
\quad\left(L_{\mathrm{Co}}, \mu \mathrm{m}\right)\end{array}$ & $\begin{array}{l}\text { Average grain } \\
\text { size } d_{\mathrm{wc}}, \mu \mathrm{m}\end{array}$ & $\begin{array}{l}\text { The size of } \\
\text { large grains of } \\
\text { WC and their } \\
\text { clusters, } \mu \mathrm{m}\end{array}$ \\
\hline VS & D2 $0.3-D 30.3$ & $62 \times 3,51 \times 1$ & $0.5-1.0(1.5)$ & 1.35 & $8-12(45)$ \\
\hline ES & A1 0.01 & no & $0.4-0.5(0.82)$ & 1.13 & $8-14(20)$ \\
\hline
\end{tabular}

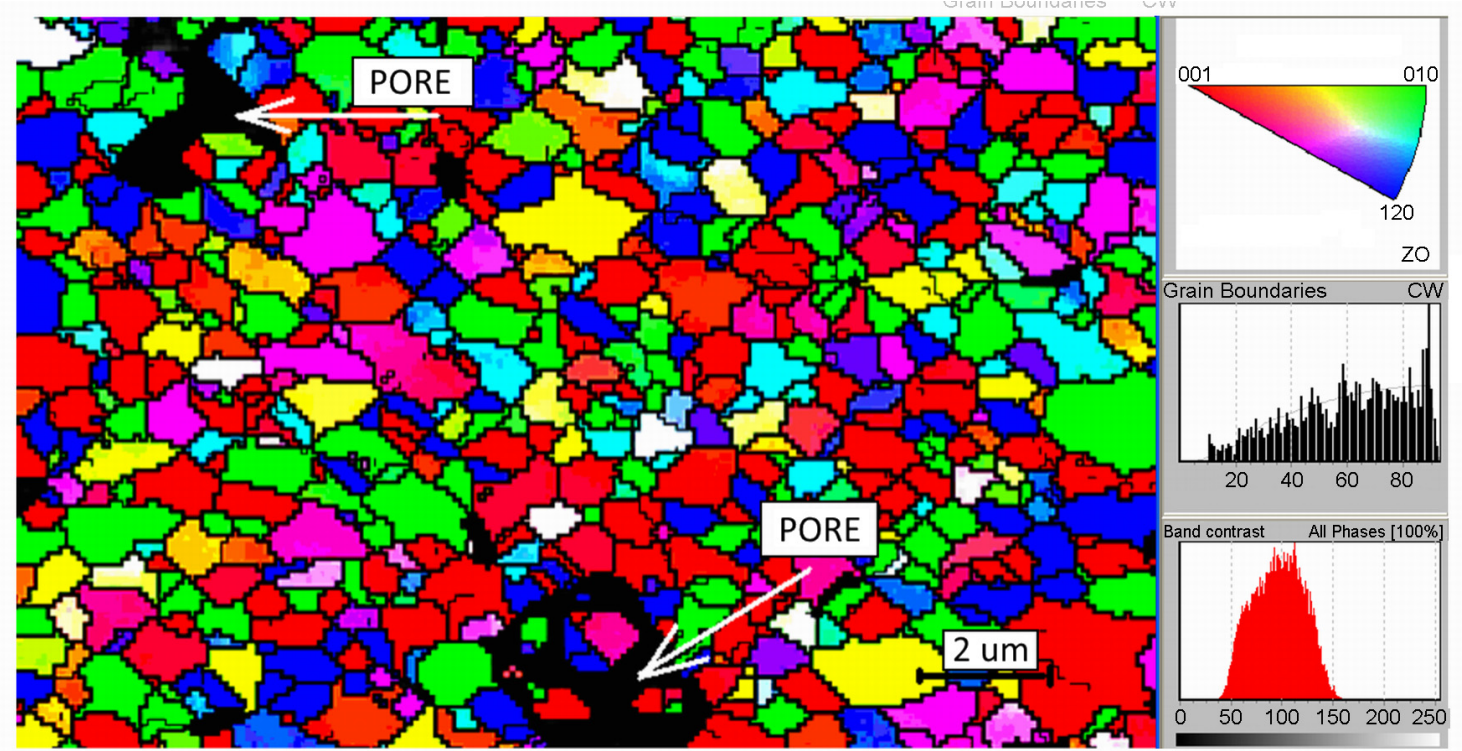

Fig. 1. Images in color orientation of WC grains with boundaries (black) between them in the sample structure (VS). The Kikuchi line method. SEM.

mixture of VK6-OM after VS and ES are given in Table 1 .

As shown by the research results, the characteristics of the samples after VS and ES by chemical composition (Table 1), the average size of the carbide grain, and the Co layer sizes (Table 2) belong to the particularly fine grained class.

As can be seen from Fig. 1 the WC grains have a shape characteristic for these sintering conditions. Black spots (shown by arrows) correspond to the layers of $\mathrm{Co}$ and times. Black spots larger than $2 \mu \mathrm{m}$ (shown by arrows) are residual pores. In Fig. 2 it is shown graphs of the distribution of the grain sizes WC and Co layers in the structure of the sample after ES.

Large residual microporosity, individual large pores with a size $>50 \mu \mathrm{m}$, a wide range of sizes of carbide grains and Co layers, the presence of separate large WC grains and their clusters (Table 2) in the structure of the sample after VS is explained in the literature by the peculiarity of free sintering conditions in vacuum. The presence in the structure of the submicron alloy after the sun of a large $(45 \mu \mathrm{m})$ size of individual clusters of large WC grains is not typical for it (Table 2). However, after ES in the sample structure, the residual microporosity was significantly reduced to A1 0.01 , and there were no separate large pores larger than $50 \mu \mathrm{m}$. Smaller average grain size WC is due to the presence of up to 10-12\% of fraction of $0.2-0.4 \mu \mathrm{m}$ in size, in contrast to the sample after VS. An important factor is also the decrease in the interval $(0.3-0.6 \mu \mathrm{m})$ of dimensions of the Co layers. According to Gorland such an interval of the dimensions of the Co interlayers in the structure of hard alloys of the WC-Co group provides them with a high level of mechanical strength.

In the sample after $\mathrm{ES}$, the separate grains of tungsten carbide up to $12 \mu \mathrm{m}$ in size were also identified (Table 2). At the same time, the size of their individual clus- 


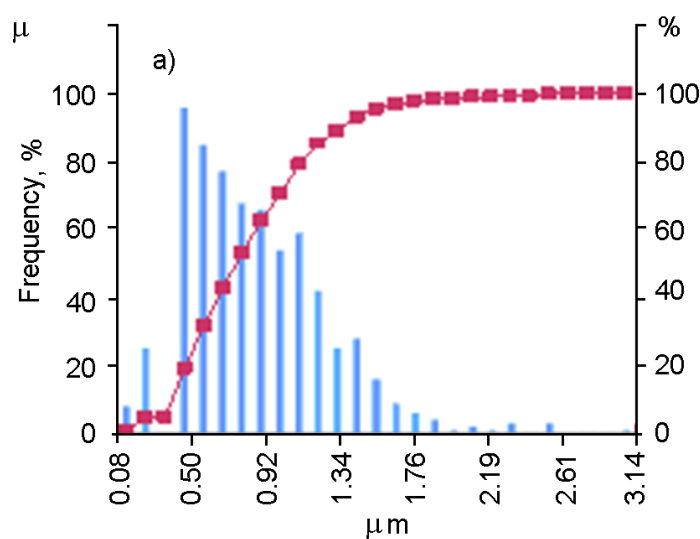

Fig. 2. Graphs of distribution of grain sizes WC

ters was smaller of about $20-25 \mu \mathrm{m}$. Despite the intense compaction conditions, it can be argued that free graphite, the large WC grains and their agglomerates were present in the initial mixture. In this case, the large agglomerates of carbide grains under ES were subjected to grinding. In Table 3 it is shown the values of the samples physico-mechanical properties after VS, ES and for the best foreign analogs (N1 and K1) [9, 10].

According to analysis of the data of Table 3 the density and hardness of the sample after VS (1) coincide with the analogous values of the standard submicron solid alloy BK6-OM [2]. Its fracture toughness is somewhat higher than the fracture toughness of the foreign analogs. Explanation of this can be both different methods of determination, as well as different values of the microporosity of their structure. The ther-

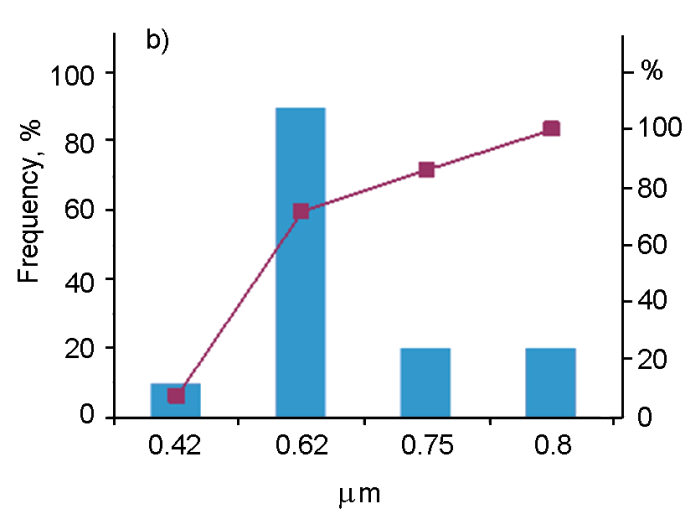

(a) and Co (b) in the sample structure (ES).

mal conductivity corresponds to the thermal conductivity of the standard mediumgrained hard alloy BK6 [3]. It should be noted that there is no data on the thermal conductivity of this type of hard alloy in the open sources of information. Thus, an interesting scientific result has been obtained, which indicates that there is no dependence of the thermal conductivity of the WC-6 \% Co hard alloy on the carbide grain size.

As it turned out after the ES (item 2), the sample density at the level of the maximum value regulated by GOST, correlates naturally with the minimal residual microporosity of its structure (see Table 2). It represents the significant scientific and practical interest in significant (by $30 \%$ and $38 \%$ ) increase of thermal conductivity and crack resistance of the sample after ES (paragraph 2). Essential (by $30 \%$ ) increase

Table 3. Comparative physical and mechanical properties of samples of submicron hard alloys group WC-6Co

\begin{tabular}{|c|c|c|c|c|c|}
\hline \multirow[t]{2}{*}{ No. } & \multirow{2}{*}{$\begin{array}{l}\text { Samples } \\
\text { sintering } \\
\text { conditions }\end{array}$} & \multicolumn{4}{|c|}{ Structure characteristics } \\
\hline & & Destiny $\gamma, \mathrm{g} / \mathrm{cm}^{3}$ & $\begin{array}{c}\text { Thermal } \\
\text { conductivity } \lambda \text {, } \\
\mathrm{W} / \mathrm{m} \cdot \mathrm{K}\end{array}$ & $\begin{array}{l}\text { Hardness HRA HV } \\
\text { (15), GPa }\end{array}$ & $\begin{array}{c}\text { Fracture } \\
\text { toughness, } K_{1 \mathrm{C}}, \\
\mathrm{MPa} \cdot \mathrm{m}^{1 / 2}\end{array}$ \\
\hline \multirow[t]{2}{*}{1} & \multirow[t]{2}{*}{ VS } & \multirow[t]{2}{*}{14.64} & \multirow[t]{2}{*}{61} & 90.2 & \multirow[t]{2}{*}{11.4} \\
\hline & & & & 16.10 & \\
\hline \multirow[t]{2}{*}{2} & \multirow[t]{2}{*}{$\mathrm{EC}$} & \multirow[t]{2}{*}{14.99} & \multirow[t]{2}{*}{90} & 93.2 & \multirow[t]{2}{*}{15.3} \\
\hline & & & & 18.20 & \\
\hline \multirow[t]{2}{*}{3} & \multirow[t]{2}{*}{$\mathrm{N} 1 *$} & \multirow[t]{2}{*}{14.77} & \multirow[t]{2}{*}{-} & 93.3 & \multirow[t]{2}{*}{9.0} \\
\hline & & & & 18.10 & \\
\hline \multirow[t]{2}{*}{4} & \multirow[t]{2}{*}{$\mathrm{K} 1^{* * *}$} & \multirow[t]{2}{*}{14.88} & \multirow[t]{2}{*}{-} & 92.7 & \multirow[t]{2}{*}{9.3} \\
\hline & & & & 17.26 & \\
\hline
\end{tabular}

$K_{1 \mathrm{C}}$, was determined according to Palquist (loading $P=750 \mathrm{~N}$ );

$*\left({ }^{* *}\right)$ the data from [5] VK6 - $62 \mathrm{~W} / \mathrm{m} \cdot \mathrm{K}$. 


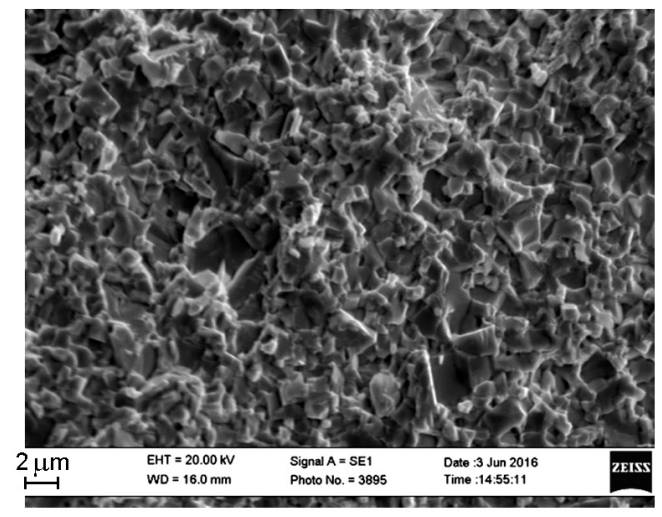

a)

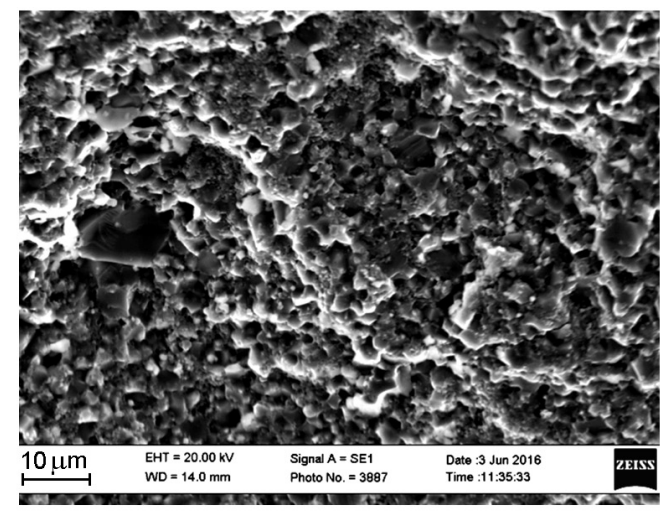

b)

Fig. 3. Fractograms of samples after sintering under different conditions: VS (a), ES (b).

of thermal conductivity, as well as crack resistance (by $38 \%$ ) can be explained by change in the state of the intercarbide boundaries.

As the results of the research show, the electrosparking significantly affects the grain boundaries, increasing the thermal conductivity, hardness, and fracture toughness of the samples, compared with the samples after VS. In this case, there is significant increase of two characteristics - hardness and fracture toughness.

Such an increase in properties, with smaller average size $\left(d_{\mathrm{WC}}\right)$ of the carbide grain, in addition to the less residual porosity of the structure (Table 3), is explained by increase in the strength of the intercarbide boundaries. The obtained value of the hardness of the sample after ES is at the level of hardness of the best grades of hard alloy of this group of leading manufacturers of the world (pos. 3, 4). Fractograms of the samples after the VS and ES are shown in Fig. 2. The fractograms of both samples confirmed the results of Table 2 of presence in their structures the individual large grains of WC and their clusters. Considering the intensive electrosparking conditions at which the recrystallization process is unlikely to proceed, it can be asserted that such grains are present in the initial mixture. The fracture of the sample after ES is more relief than the sample after VS, as evidenced by the high contrast (the presence of light and dark colors in the electronic image).

As can be seen from Fig. 2a the samples after the VS are destroyed by intercristality mechanism, which is characteristic for destruction of this type of hard alloys with grains of tungsten carbide recrystallized to prismatic shape. For the sample after ES (Fig. 2b), the destruction is also mainly intercrystallite in the structure with the grain size of less than $2 \mu \mathrm{m}$, which have rounded non-recrystallized shape. At the same time, the grains more than $4 \mu \mathrm{m}$ are transcristally destroyed. It is also important to note that on the surface of the sample breaking after the ES the greater surface relief was revealed, which is caused by the protrusions and depressions both from individual grains and from their accumulations. In this case, this can be uniquely consequence of the high strength of the grain boundaries.

\section{Conclusions}

The research of the structure formation and physico-mechanical properties of the hard alloy from commercial grade BK6-OM powder under standard vacuum free sintering and electrosparking in vacuum at liquid-phase $\left(T=1320^{\circ} \mathrm{C}\right)$ and solid-state $(T=$ $1200^{\circ} \mathrm{C}$ ) under conditions of intense compaction at pressure of $P=40 \mathrm{MPa}$ was performed and the following results were obtained:

- under the conditions of standard free sintering in vacuum, characteristic structure for the BK6M alloy is formed, which is associated with the recrystallization of carbide grains;

- under conditions of ES at temperature $\left(T=1320^{\circ} \mathrm{C}\right)$ the structure with inclusions of the $\eta$-phase is formed, not allowed by GOST;

at temperature $T=1200^{\circ} \mathrm{C}$ the finegrained, two-phase, high-density structure with a granulometric composition is formed, which is regulated by GOST for the hard alloy BK6OM;

- the presence of individual coarse grains of up to $12 \mu \mathrm{m}$ and their clusters up to $20 \mu \mathrm{m}$ in size is observed, which under the conditions of ultrahigh high-speed solid- 
phase compaction and short-term (3 min) isothermal exposure is due to their presence in the initial mixture;

- the presence of the large (up to $2 \%$ ) oxygen content correlates with the oxygen content in the initial mixture, which, unlike vacuum sintering, is not removed from the sample through intensive compaction conditions;

- there is increase of the thermal conductivity by $30 \%$, hardness, crack resistance by $5.0 \mathrm{MPa} \cdot \mathrm{m}^{1 / 2}$ compared to the sample after the sun, due to the high density of the structure, the strength of the grain boundaries, and the narrow (0.4$0.5 \mu \mathrm{m}$ ) size interval Co layers.

\section{References}

1. W.D.Schubert, Ultrafine and Nanograinedhardmetals: "State of the Art" - Their Properties and Application, Institut Sverhtverdyh Materialov, Kiev (2008).

2. M.Kramer, V.Kodash, E.Gevorkyan, Intern. Patent WO 2005/023729 A1.

3. V.S.Panov, A.M.Chuvilin, V.A.Falkovskiy, Technology and Properties of Sintered Hard Alloys and Products Made from them, MISiS, Moscow (2004) [in Russian].

4. V.A.Falkovskiy, L.I.Klyachko, Solid Alloys, Izdatelskiy Dom "Rudaimetally", Moscow (2005) [in Russian].

5. V.I.Tretyakov, Basics of Metal Science and Technology of Production of Sintered Hard Alloys, Metallurgiya, Moscow (1976) [in Russian].

6. V.P.Bondarenko, E.G.Pavlotskaya, Sintering of Tungsten Hard Alloys in a Precisely Controlled Gas Environment, Naukova Dumka, Kiev (1995).

7. N.M.Prokopiv, V.P.Bondarenko, O.V.Harchenko, I.A.Gnatenko, Sverhtv.Mat., 47, 6 (2006).
8. H.Chen, D.Zwang, Y.Li, J.Chen, Proc. 15 Intern. Plansee Seminar, 180, 2 (2001).

9. USA Patent 6228139 (2001).

10. M.M.Prokopiv, O.V.Harchenko, Vesn.NTU "HPI", 149, 57 (2013).

11. Ukraine Patent for Invention No. 90830.

12. A.V.Laptev, Porosh. Metal., 8, 3 (2001).

13. M.S.Kovalchenko, Porosh.Metal., 98, 1 (2001).

14. A.V.Ragulya, V.V.Skorohod, Consolidated Nanostructured Materials, Naukova Dumka, Kiev (2007) [in Russian].

15. R.Orru, R.Licheri, A.M.Locci et al., Mater. Sci.Eng., 127, 63 (2009)

16. Ukraine Patent No.72841 (2012).

17. E.S.Gevorkyan, L.A.Timofeeva, V.A.Chishkala, P.S.Kislyiy, Nanostrukt. Mat., 46, 2 (2006).

18. E.Gevorkyan, Y.Gutsalenko, N.Prokopiv, Durab.Fiab., 1, 7 (2011).

19. Basics of EBSD http:// www.ebsd.com/ index.htm.

20. Yu.I.Azima, Yu.I.Belyaev, M.V.Kulakov, Prib. i Teh. Eksp., 248, 4 (1985).

21. USA Patent $6,617,271$ (2003).

22. E.Sgourou, Y.Panayiotatos, R.V.Vovk, A.Chroneos, Appl. Sci., 674 (2017), doi:10.3390/app7070674.

23. O.V.Dobrovolskiy, M.Huth, V.A. Shklovskij, R.V.Vovk, Sci. Rep., 7:13740, doi:10.1038/s41598-017-14232-z.

24. O.V.Dobrovolskiy, V.V.Sosedkin, R.Sachser et al., J.Supercond Nov.Magn., 30, 735 (2017), doi:10.1007/s10948-016-3642-8.

25. A.L.Solovyov, L.V.Omelchenko, V.B.Stepanov et al., Phys. Rev. B, 94, 224505 (2016).

26. M.A.Hadi, M.Roknuzzaman, A.Chroneos et al.,Comput. Mater. Sci., 137, 318 (2017).

27. M.A.Hadi, R.V.Vovk, A.Chroneos, Journal of Materials Science: Mater. in Electron., 27, 11925 (2016), doi:10.1007/s10854-016-5338-z. 